\title{
ДЕРЖАВНА ІННОВАЦІЙНА ПОЛІТИКА ВДОСКОНАЛЕННЯ ІНВЕСТИЦЙНО-БУДІВЕЛЬНОГО КОМПЛЕКСУ УКРАЇНИ
}

Шведун B.O., д-р наук з держ. упр., професор, Національний аерокосмічний університет імені М. С. Жуковського «Харківський авіаційний інститут», м. Харків, Україна.

Грень Л. М., д-р наук 3 держ. упр., професор, доцент, Національний технічний університет «Харківський політехнічний інститут», м. Харків, Україна.

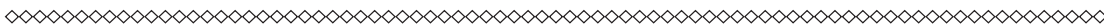

У статті запропоновано напрями розвитку державної інноваиійної політики вдосконалення інвестиційно-будівельного комплексу України. Зокрема, охарактеризовано основні напрями $і$ технології інноваційної діяльності в будівництві в Україні. Проаналізовано структуру і динаміку зміни капітальних інвестицій у будівельний комплекс Украӥни. Виокремлено напрями формування та реалізачії державної інноваційної політики щуодо вдосконалення інвестичійнобудівельного комплексу України. Серед основних заходів, реалізація яких дозволила б вивести будівельний комплекс України з кризового стану, виділено такі: перехід до реальної структурної й інституційної реформи украӥнської економіки; реалізація ефективної інвестиційної політики, орієнтованої на подолання поточних структурних змін негативного впливу; формування державно-приватного партнерства. Запропоновано впровадження гарантій для будівельних компаній в складі державно-приватного-партнерства, які уможливлять отримання більшої фінансової стійкості: гарантії завершення будівництва в розумні терміни за рахунок участі держави; гарантії одержання найменшої на ринку иіни за рахунок відсутності паразитних (трансакційних) витрат і оптимізації витрат на придбання земельних ділянок, будівництво та інфраструктуру. 
Ключові слова: державна інноваџійна політика, інвестииійнобудівельний комплекс, державно-приватне партнерство, інвестиційна політика, капітельні інвестииії.

Постановка проблеми у загальному вигляді. Інвестиційнобудівельний комплекс є відкритою системою організаційно-господарського типу, в умовах якої здійснюються товарно-грошові відносини між суб'єктами - елементами інвестиційно-будівельного комплексу (інвесторами, замовниками, підрядниками, проектними інститутами, підприємствами-виробниками будівельних матеріалів і ін.), а також реалізація їх взаємних економічних інтересів.

Організаційна структура інвестиційно-будівельного комплексу $€$ не тільки виробничою структурою, але й органом, який пропонує інформаційні послуги у сфері будівельної діяльності, якому сьогодні необхідно шукати інноваційні форми економічного співробітництва 3 державою (державними та місцевими органами влади) та банками, структурами комерційного спрямування, що уможливило би вироблення доцільної й ефективної інвестиційної політики в регіонах України, а також сприяло б розвитку системи іпотечного кредитування. Відповідно, вищезазначене обумовлює актуальність обраної теми дослідження.

Аналіз останніх досліджень і публікацій. Питання, що стосуються формування та реалізації державної політики у сфері інвестиційно-будівельного комплексу, зокрема, відповідних інновацій, досліджувалися у наукових працях таких вітчизняних і зарубіжних авторів, як: А. Блейз, М. Дулаїмі, О. Кириленко, П. Матвієнко, А. Омельянович, Й. Шкура [14] ті ін.

Однак питання розробки та впровадження дієвої державної інноваційної політики вдосконалення інвестиційно-будівельного комплексу України все ще потребують подальшого опрацювання.

Формулювання цілей статті (постановка завдання). Метою роботи $є$ розвиток державної інноваційної політики вдосконалення інвестиційно-будівельного комплексу України. 
Для досягнення поставленої мети у роботі ставляться та вирішуються наступні завдання:

- охарактеризувати основні напрями і технології інноваційної діяльності в будівництві в Україні;

- проаналізувати структуру і динаміку зміни капітальних інвестицій у будівельний комплекс України;

- виокремити напрями формування та реалізації державної інноваційної політики щодо вдосконалення інвестиційно-будівельного комплексу України.

Виклад основного матеріалу дослідження. Основними напрямами інноваційної діяльності в будівництві $є$ наступні:

- нововведення в проектуванні житлових будинків, об'єктів соціальної та виробничої сфери, транспортних систем і комунікацій;

- нові технології, матеріали, обладнання, методи управління будівництвом, пов'язані з комплексною безпекою, енергоефективністю та екологією, що сприяє підвищенню якості і зниженню термінів будівництва.

Новітні технології сьогодні розвиваються дуже стрімко і зачіпають буквально кожну сферу людської діяльності. Хто володіє технологією, той захоплює лідерство і в будівельному сегменті. Розробка і виробництво нових будівельних матеріалів грає велику роль в удосконаленні будівельних технологій, а також поліпшенні якості різних складових виробничих і житлових будівель.

Нові технології в будівництві представляють можливим:

- підвищити теплоізоляційні властивості будинків, також внаслідок цього знижуються і витрати на експлуатацію житла і його собівартість;

- скоротити терміни безпосереднього будівництва об'єкта;

- знизити витрати, підвищити якість споруди, і1і довговічність й інші показники $[10 ; 18 ; 20]$.

Освоєння і впровадження нових будівельних матеріалів має велике значення в удосконаленні будівельних технологій, а також підвищенні якості різних складових будівель і споруд.

При цьому ключовими принципами застосування нових будівельних матеріалів при зведенні будівель і споруд $є$ наступні. 
1. Нові матеріали повинні перевершувати за якістю і характеристиками аналогічні традиційні матеріали.

2. Нові матеріали повинні підвищити рентабельність продажів.

3. Надійність і простота застосування.

4. Використання при виробництві вдосконалених матеріалів недорогих компонентів і активних хімічних добавок, що роблять їх собівартість нижчою, ніж у тих, що застосовувалися раніше.

5. Екологічність інноваційних матеріалів. Зокрема, нова архітектурно-будівельна система «IMET» $є$ розвитком каркасних систем і включає зведення трубобетонних пальових фундаментів, швидко монтованих збірних каркасів 3 несучих трубобетонних колон з вузлами сполучення заводської готовності замість широко застосовуваних залізобетонних колон, в поєднанні з перекриттями 3 перенапруженого бетону з натягом на бетон в умовах будівельного майданчика і застосування навісних панелей з теплоізоляцією на основі капсульованого керамзитового гравію або піноскла (технологія «КАПСІМЕТ») з оригінальною системою забезпечення пожежної безпеки багатоповерхових і висотних будівель $[4 ; 6 ; 10]$.

Нова система може служити технологічною основою масового збірного будівництва будинків будь-якої поверховості з комплектуючих без застосування монолітних трудомістких робіт з арматурою і бетоном, відповідаючи умовам:

- максимально високій швидкості будівництва;

- цілорічного будівництва в незалежності від погоди;

- мінімальної матеріаломісткості;

- екологічної чистоти;

- надійності;

- довговічності.

Основні переваги нових систем:

- підвищення рівня комфортності і необмеженої різноманітності об'ємно-планувальних побудов, трансформація планувальних рішень при будівництві й експлуатації будівель;

- зниження собівартості будівництва житлових і громадських будівель, що робить будівництво житла доступнішим масовому споживачеві; 
- зниження рівня матеріало- і енерговитрат на будівництво й утримання житлових і громадських будівель;

- підвищення ефективності будівельного виробництва за рахунок максимального використання наявної місцевої сировинної та виробничої бази;

- впровадження і можливість застосування сучасних ефективних регульованих інженерних систем (поквартирного опалення, вентиляції та кондиціонування та ін.);

- високий темп зведення будівель, усепогодність будівництва при мінімальних витратах, в тому числі і в зимових умовах.

Додатковими причинами незацікавленості будівельних організацій в реалізації нових технологій є:

- певні ризики при застосуванні інновацій;

- відсутність достатньої інформації про нові технології і досягнення в будівництві;

- масова дискваліфікація проектувальників, інженерів і вчених, робітників і керівників, низький рівень знань і професійної підготовки;

- розпад галузевих технологічних інститутів, застосування проектними інститутами застарілих технічних рішень;

- відсутність мотивації в зниженні витрат металу і бетону, зменшення енерго- і трудовитрат;

- недосконалість кошторисних розрахунків вартості будівництва $[6 ; 9]$.

- Слід зазначити, що у 2019 році загальний обсяг капітальних інвестицій в Україні збільшився на 15,5\% порівняно 3 попереднім 2018 роком та склав 584,4 млрд. грн. При цьому ключовими драйверами інвестицій у 2019 році стали промисловість і будівництво (35\%), сільське господарство (10\%) та інформація і телекомунікації $(17 \%)$.

Відповідно, розподіл капітальних інвестицій в Україні протягом 2018-2019 років наведено в табл. 1 [13]. 
Таблиця 1

Відсотковий розподіл капітальних інвестицій у будівельний комплекс України за джерелами фінансування протягом 2018-2019 років

\begin{tabular}{|c|c|c|}
\hline Джерело фінансування & 2018 & 2019 \\
\hline $\begin{array}{c}\text { Бюджетні кошти } \\
\text { Банківські кредити та інші }\end{array}$ & 12,7 & 14,6 \\
\hline $\begin{array}{c}\text { позик } \\
\text { житла }\end{array}$ & $7,7,0$ \\
\hline $\begin{array}{c}\text { Кошти інвесторів іноземного } \\
\text { походження }\end{array}$ & 71,3 & 6,4 \\
\hline Інші джерела & 2,9 & 4,7 \\
\hline
\end{tabular}

3 табл. 1 можна побачити, що протягом 2018-2019 років найбільшу частку у загальному відсотковому розподілі капітальних інвестицій у будівельний комплекс України за джерелами фінансування складають кошти інвесторів іноземного походження. Однак у 2019 році їх обсяг дещо зменшився - на 3,2\%.

Що стосується розподілу капітальних інвестицій у будівництво протягом 2018-2019 років за видами активів, то його наведено у табл. 2 [13].

3 табл. 2 можна побачити, що найбільшу частку у загальному відсотковому розподілі капітальних інвестицій у будівельний комплекс України за видами активів протягом 2018-2019 років складають машини, обладнання та інвентар. При цьому їх частка у 2019 році збільшилася на $0,9 \%$. 
Таблиця 2

\section{Відсотковий розподіл капітальних інвестицій у будівельний комплекс України за видами активів протягом 2018-2019 років}

\begin{tabular}{|c|c|c|}
\hline Вид активів & 2018 & 2019 \\
\hline Житлові будинки & 10,1 & 9,5 \\
\hline Нежитлові будинки & 14,7 & 15,4 \\
\hline Інженерні споруди & 19,4 & 22,6 \\
\hline $\begin{array}{c}\text { Машини, обладнання та } \\
\text { інвентар }\end{array}$ & 33,1 & 34,0 \\
\hline Нематеріальні активи & 12,1 & 10,8 \\
\hline Інші нематеріальні активи & 10,6 & 7,7 \\
\hline
\end{tabular}

Аналіз змісту програм державної підтримки житлового будівництва, а також низка програм регіонального рівня дає можливим зробити однозначний висновок про те, що обсяги державної підтримки будівельного комплексу в даний час явно недостатні, відсутні система цільового державного фінансування [4].

Необхідно, щоб в планах держави на найближчі роки був закладений високий рівень державної підтримки будівництва, отже, можна очікувати підвищеної уваги до будівельної галузі на державному рівні. Що стосується розвитку малоповерхового сегмента - то одними з головних перешкод на шляху розвитку ринку $\epsilon$ недоробки земельного кодексу. Механізми придбання землі у власність залишаються непрозорими для пересічних покупців, вартість оформлення пакету документів висока, існує безліч нез'ясованих нюансів і проблем щодо виділення й оформлення земельних діля- 
нок, що створюють базис для розвитку корупції. Ідентична ситуація склалася і в сфері забезпечення земельних ділянок комунальною інфраструктурою.

Одними з основних заходів, реалізація яких дозволила б вивести будівельний комплекс України з кризового стану, є такі:

- перехід до реальної структурної й інституційної реформи української економіки;

- реалізація ефективної інвестиційної політики, орієнтованої на подолання поточних структурних змін негативного впливу;

- формування державно-приватного партнерства, що, з одного боку, могло б сприяти розукрупненню низки існуючих акціонерних товариств, які стали монополістами в межах конкретного будівельного ринку, а з іншого - дозволили б поглинути ряд акціонерних товариств, як структур, які змінили державну форму власності на акціонерну, але зберегли колишній принцип господарсько-економічних взаємин із замовником, очікування авансування, а не оплату завершених і зданих в експлуатацію об'єктів [5; 7].

Будівельні компанії в складі державно-приватного-партнерства повинні отримати більшу фінансову стійкість і державні гарантії, наприклад:

- гарантії завершення будівництва в розумні терміни за рахунок участі держави;

- гарантії одержання найменшої на ринку ціни за рахунок відсутності паразитних (трансакційних) витрат і оптимізації витрат на придбання земельних ділянок, будівництво та інфраструктуру.

Подібні утворення фінансово-промислового типу могли б сприяти:

• поліпшенню інвестиційного клімату в країні;

- забезпеченню стабілізації господарських і коопераційних зв'язків;

- припиненню тенденції неплатежів;

- формуванню внутрішнього конкурентного середовища;

- розвитку ринку підрядних робіт в Україні.

У зв'язку зі сформованою ситуацією державі й інвестиційнобудівельного комплексу необхідно виробити такі напрями, які, не 
порушуючи ринкових принципів функціонування житлової сфери, не підвищуючи ризиків для діяльності приватних інвесторів, кредитних організацій, девелоперів, будівельних компаній, підприємств будівельної індустрії й інших господарюючих суб'єктів, що дозволили б вирішувати проблеми доступності житла для громадян України. Це можливо на принципах державно-приватного партнерства з використанням державних і муніципальних фінансів [3; 8].

Значно підвищується роль держави в розробці і контролі виконання законодавства в галузі будівництва. Для цього необхідно, щоб всі учасники ринку були в рівних умовах, потрібні бути чітко прописані відповідні правила і механізми на державному рівні.

Висновки. Таким чином, державою в інвестиційно-будівельній сфері повинні бути закладені об'єктивні передумови для ефективної роботи як окремих будівельних компаній, так і інтегрованих структур в цілому в ринкових умовах, обумовлені постійною потребою в будівельній продукції, зокрема, в соціальній сфері, а також мають бути визначені оптимальні пропорції ринкової економіки і державного регулювання. Як показує зарубіжний досвід, така державна участь дозволяє перетворити будівельну галузь в один із найбільш рентабельних секторів національної економіки.

У цілому, враховуючи вищезазначене, державі слід реалізувати стратегію переходу інвестиційно-будівельного комплексу до нових економічних відносин в новій організаційній структурі галузі. Дана структура повинна формуватися виключно з міркувань економічної доцільності функціонування будівельних компаній і інтегрованих структур змішаних форм власності. Така стратегія може бути реалізована лише в рамках загальної концепції нової інвестиційної політики.

\section{Стаття надійшла до редакції: 19.09.20}




\section{STATE INNOVATIVE POLICY OF IMPROVING OF THE INVESTMENT AND CONSTRUCTION COMPLEX OF UKRAINE}

Viktoriia Shvedun, Doctor of Sciences in Public Administration, Professor, National Aerospace University H.E. Zhukovsky «Kharkiv Aviation Institute», Kharkiv, Ukraine.

Larysa Hren, Doctor of Sciences in Public Administration, Professor, National Technical University «Kharkiv Polytechnic Institute», Kharkiv, Ukraine.

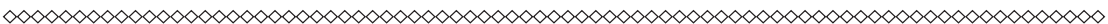

The article proposes directions of development of the state innovation policy on improving of the investment and construction complex of Ukraine. In particular, the following main directions and technologies of innovation activity in construction in Ukraine are described: innovations in the design of residential buildings, social and industrial facilities, transport systems and communications; new technologies, materials, equipment, construction management methods related to complex safety, energy efficiency and ecology, which contributes to improving of quality and reducing of construction time. The structure and dynamics of changes in capital investments in the construction complex of Ukraine are analyzed. The directions of formation and implementation of the state innovation policy on improvement of investment and construction complex of Ukraine are highlighted. The following ones are highlighted among the main measures whose implementation would make it possible to remove the construction complex of Ukraine from the crisis state: transition to real structural and institutional reform of the Ukrainian economy; implementation of effective investment policies aimed at overcoming current structural changes of negative impact; formation of publicprivate partnerships. It is proposed to introduce the following guarantees for construction companies as part of a public-private partnership, which will make them more financial sustainable: 
guarantees of construction completion within a reasonable time at the expense of state participation; guarantees of the lowest price on the market due to absence of parasitic (transaction) costs and optimization of costs for land, construction and infrastructure acquisition.

Thus, the state in the investment and construction sector should lay objective prerequisites for effective operation of both individual construction companies and integrated structures in general in market conditions, due to the constant need for construction products, in particular in the social sphere, with the possibility of determining of the optimal proportions of the market economy and state regulation. As foreign experience shows, such state participation makes it possible to turn the construction industry into one of the most profitable sectors of the national economy.

Key words: state innovation policy, investment and construction complex, public-private partnership, investment policy, capital investments.

\section{Received: 19.09.20}

\section{References}

1. Kachur, R.P. (2013). Instytucijna struktura i normatyvno-pravove zabezpechennya regulyuvannya investycijnogo rynku v umovach transformaciyi ekonomiky [Institutional structure and regulation of the investment market in the context of economic transformation]. Naukovyi visnyk Natsionalnoho lisotekhnichnoho universytetu Ukrainy : zb. nauk.-tekhn. prats - Scientific Bulletin of the National Forestry University of Ukraine: collection. scientific and technical wash, 23.7, (pp. 241-248) [in Ukrainian].

2. Kyrylenko, O.P. (2008). Teoriya i praktyka byudzhetnych investycij [Theory and practice of budget investments]. Ternopil : Ekonomichna dumka [in Ukrainian].

3. Kovtun, O.I. (2006). Derzhavne regulyuvannya ekonomiky [State regulation of economy]. Lviv : Novyj svit [in Ukrainian]. 
4. Koncepciya Derzhavnoyi cilovoyi ekonomichnoyi programy na 20112015 roky [Concept of the state target economic program on 2011-2015]. www. rada.gov.ua. Retrieved from www.rada.gov.ua [in Ukrainian].

5. Kuzmin, O.Ye. (2002). Regulyuvannya investycijnoyi diyalnosti v Ukrayini [Regulation of investment activity in Ukraine]. Finansy Ukrayiny Finance of Ukraine, 3 (76), (pp. 97-108) [in Ukrainian].

6. Kuchta, P.V.b (2012). Napryamy vdoskonalennya derzhavnogo regulyuvannya investycijnoyi diya'nosti vitchy`znyanyx pidpryyemstv [Directions of improvement of state regulation of investment activities of domestic enterprises]. Biznes Inform. - Business Inform., 11, (pp. 55-58) [in Ukrainian].

7. Majorova, T.V. (2004). Investycijna diyalnist: navch. posibnyk [Investment activity : manual]. Kyiv : CzUL [in Ukrainian].

8. Marcyn, V.S. (2005). Ekonomichne regulyuvannya innovacijnoyi diyalnosti [Economic regulation of innovative activity]. Finansy Ukrayiny Finance of Ukraine, 5, (pp. 44-53) [in Ukrainian].

9. Matviyenko, P.V. (2007). Pokrashhennya investycijnogo klimatu priorytetne zavdannya derzhavnogo upravlinnya [Improving of investment climate is a priority of public administration]. Investyciyi: praktyka ta dosvid Investments: practice and experience, 1 [in Ukrainian].

10. Mykytyuk, P.P. (2009). Procedury investycijno-innovacijnogo analizu na pidpryyemstvax budivelnoyi galuzi [Procedures for investmentinnovation analysis at construction industry enterprises]. Visnyk Ternopilskogo nacionalnogo ekonomichnogo universytetu - Visnyk of Ternopil National University of Economics, 3, (pp. 105-111) [in Ukrainian].

11. Mojseyenko, I.P. (2009). Informacijno-analitychne zabezpechennya finansovoyi bezpeky subyektiv gospodaryuvannya [Information and analytical support of financial security of economic entities]. Aktualni problemy ekonomiky - Actual problems of economy, 10, (pp. 233-238) [in Ukrainian].

12. Omelyanovych, A.R. (2012). Investuvannya : monografiya [Investment : monograph]. Kyiv : KNEU [in Ukrainian].

13. Standartnyj zvit z yakosti derzhavnogo statystychnogo sposterezhennya «Kapital'ni investyciyi» [Standard Report on Quality of State Statistical Observation «Capital Investments»]. ukrstat.gov.ua. Retrieved from http:// ukrstat.gov.ua [in Ukrainian]. 
14. Shkura, J.S. (2003). Osobennosty formyrovanyia fynansovoho mekhanyzma ynvestytsyonnykh protsessov [Features of the formation of the financial mechanism of investment processes]. Akademichnyi ohliad-Academic Review, 2, (pp. 35-39) [in Russian].

15. Blayse, A. \& Manley, K. (2004). Key influences on construction innovation, Construction Innovation, 4, (pp. 143-154) [in English].

16. Dulaimi, M. \& Nepal, M. \& Park, M. (2005). A Hierarchical Structural Model of Assessing Innovation and Project Perfomance. Construction Management and Economics, 23.6, (pp. 565-577) [in English].

17. Gann, D.I.M. (2000). Building Innovation: Complex Constructs in a Changing World [in English].

18. Kangali, R. \& Miyatake, Y. (1997). Developing and Managing Innovative Construction Technologies in Japan. Journal of Construction Engineering and Management, 123.1, (pp. 72-78) [in English].

19. Ling, F.Y.Y. (2003). Managing the implementation of construction innovations. Construction Management and Economics, 21, (pp. 635-649) [in English].

20. Nam, C.H. \& Tatum, C.B. (1997). Leaders and champions for construction innovation. Construction Management Economics, 15, (pp. 259-270) [in English].

21. Reichstein, T. \& Salter, A.J. \& Gann, D.M. (2005). Last among equals: a comparison of innovation in construction, services and manufacturing in the I-JK. Construction Management and Economics, 23.6, (pp. 631-644) [in English].

22. Seaden, G. \& Manseau, A. (2001). Public policy and construction innovation. Building Research \& Information, 29.3, (pp. 182-196) [in English].

23. Slaughter, S. (1991). Innovation and Leaming during Implementation: a Compalison of User and Manufacturer Innovations. Research Policy, 22, (pp. 81-95) [in English].

24. Veshosky, D. (1998). Managing innovation information in Engineering and construction films. Journal of Management in Engineering, 124.1, (pp. 58-66) [in English].

25. Winch, GINI. (1998). Zephyrs of creative destriction: understanding the management of innovation in construction. Building Research \& Information, 26.4, (pp. 268-279) [in English]. 


\section{Відомості про авторів / Information about the Authors}

\section{Шведун Вікторія Олександрівна: Національний} аерокосмічний університет ім. М. Є. Жуковського «Харківський авіаційний інститут»: вул. Чкалова 17, м. Харків, 61070, Україна.

Viktoriia Shvedun: National Aerospace University H.E. Zhukovsky «Kharkiv Aviation Institute»: 17 Chkalov st., Kharkiv, 61070, Ukraine.

\section{ORCID.ORG/ 0000-0002-5170-4222}

\section{E-mail: applevikvs@gmail.com}

Грень Лариса Миколаївна: Національний технічний університет «Харківський політехнічний інститут»: вул. Кирпичова 2, м. Харків, 61002, Україна.

Larysa Hren: National Technical University «Kharkiv Polytechnic Institute»: 2, Kyrpychova str., Kharkiv, 61002, Ukraine.

ORCID.ORG/ 0000-0003-4466-6018

E-mail: mega_lgren@ukr.net 